\title{
Corrigendum: Single-Neuron Level One-Photon Voltage Imaging With Sparsely Targeted Genetically Encoded Voltage Indicators
}

\author{
Peter Quicke ${ }^{1,2,3}$, Chenchen Song ${ }^{2}$, Eric J. McKimm ${ }^{4}$, Milena M. Milosevic ${ }^{4}$, \\ Carmel L. Howe ${ }^{1,3}$, Mark Neil ${ }^{3,5}$, Simon R. Schultz ${ }^{1,3}$, Srdjan D. Antic ${ }^{4}$, Amanda J. Foust ${ }^{1,3}$ \\ and Thomas Knöpfel ${ }^{2,3 *}$ \\ ${ }^{1}$ Department of Bioengineering, Imperial College London, London, United Kingdom, ${ }^{2}$ Department of Medicine, Imperial \\ College London, London, United Kingdom, ${ }^{3}$ Centre for Neurotechnology, Imperial College London, London, \\ United Kingdom, ${ }^{4}$ Institute for Systems Genomics, Stem Cell Institute, UConn Health, Farmington, CT, United States, \\ ${ }^{5}$ Department of Physics, Imperial College London, London, United Kingdom
}

Keywords: voltage imaging, cerebral cortex, sparse expression, optogenetics, transgenic

\section{A Corrigendum on}

\section{OPEN ACCESS}

Edited and reviewed by: Josef Bischofberger,

Universität Basel, Switzerland

*Correspondence: Thomas Knöpfel tknopfel@knopfel-lab.net

Specialty section:

This article was submitted to Cellular Neurophysiology,

a section of the journal

Frontiers in Cellular Neuroscience

Received: 17 April 2019 Accepted: 23 April 2019 Published: 07 May 2019

Citation:

Quicke P, Song C, McKimm EJ, Milosevic MM, Howe CL, Neil M, Schultz SR, Antic SD, Foust AJ and

Knöpfel T (2019) Corrigendum:

Single-Neuron Level One-Photon

Voltage Imaging With Sparsely

Targeted Genetically Encoded Voltage Indicators.

Front. Cell. Neurosci. 13:202. doi: 10.3389/fncel.2019.00202
Single-Neuron Level One-Photon Voltage Imaging With Sparsely Targeted Genetically Encoded Voltage Indicators

by Quicke, P., Song, C., McKimm, E. J., Milosevic, M. M., Howe, C. L., Neil, M., et al. (2019). Front. Cell. Neurosci. 13:39. doi: 10.3389/fncel.2019.00039

In the original article, there was an error. The in-line equation for the signal-to-noise ratio in the presence of a fluorescence background was incorrectly printed as $\sqrt{\left(1-f_{b}\right) * S N R_{0}}$, where it should have been printed as $\sqrt{\left(1-f_{b}\right)} S N R_{0}$.

A correction has been made to the Introduction, paragraph six:

"Formally, the issue of single cell resolution can be described as follows: an optical signal from a cell of interest is compromised by shot noise generated by non-signaling fluorescence emanating from the membranes of other fluorescent cells and tissue autofluorescence (the "background"). The fractional change in collected fluorescence, $\Delta \mathrm{F} / \mathrm{F}$, will be reduced to $\left(1-f_{b}\right) \Delta F / F$ where $f_{b}$ is the fraction of fluorescence arising from non-signaling structures. Background fluorescence also has a detrimental effect on SNR. In a shot noise limited imaging system, SNR will be reduced proportionally to the $S N R$ measured in the absence of background fluorescence $\left(\mathrm{SNR}_{0}\right)$ as $\sqrt{\left(1-f_{b}\right)} S N R_{0}$ (Knöpfel et al., 2006). Reducing the excitation volume in an attempt to minimize the contribution of fluorescent membranes of adjacent cells and their processes, for instance by using highly localized two-photon laser scanning (2PLS) excitation, reduces the amount of non-signaling fluorescence collected at the cost of very low rates of signal-carrying fluorescence excitation resulting in low SNRs. This makes 2PLS microscopy a poor choice for most voltage imaging applications, although it has been used successfully in some experimental paradigms (Ahrens et al., 2012; Akemann et al., 2013; Chamberland et al., 2017; Chavarha et al., 2018).”

The authors apologize for this error and state that this does not change the scientific conclusions of the article in any way. The original article has been updated. 


\section{REFERENCES}

Ahrens, K. F., Heider, B., Lee, H., Isacoff, E. Y., and Siegel, R. M. (2012). Two-photon scanning microscopy of in vivo sensory responses of cortical neurons genetically encoded with a fluorescent voltage sensor in rat. Front. Neural Circuits 6:15. doi: 10.3389/fncir.2012. 00015

Akemann, W., Sasaki, M., Mutoh, H., Imamura, T., Honkura, N., and Knöpfel, T. (2013). Two-photon voltage imaging using a genetically encoded voltage indicator. Sci. Rep. 3, 1-7. doi: 10.1038/srep 02231

Chamberland, S., Yang, H. H., Pan, M. M., Evans, S. W., Guan, S., Chavarha, M., et al. (2017). Fast two-photon imaging of subcellular voltage dynamics in neuronal tissue with genetically encoded indicators. Elife 6, 1-35. doi: $10.7554 /$ eLife. 25690
Chavarha, M., Villette, V., Dimov, I., Pradhan, L., Evans, S., Shi, D., et al. (2018). Fast two-photon volumetric imaging of an improved voltage indicator reveals electrical activity in deeply located neurons in the awake brain. bioRxiv [Preprint] 445064. doi: 10.1101/445064

Knöpfel, T., Díez-García, J., and Akemann, W. (2006). Optical probing of neuronal circuit dynamics: genetically encoded versus classical fluorescent sensors. Trends Neurosci. 29, 160-166. doi: 10.1016/j.tins.2006.01.004

Copyright (® 2019 Quicke, Song, McKimm, Milosevic, Howe, Neil, Schultz, Antic, Foust and Knöpfel. This is an open-access article distributed under the terms of the Creative Commons Attribution License (CC BY). The use, distribution or reproduction in other forums is permitted, provided the original author(s) and the copyright owner(s) are credited and that the original publication in this journal is cited, in accordance with accepted academic practice. No use, distribution or reproduction is permitted which does not comply with these terms. 